\title{
Demographic patterns of the palaemonid prawn Macrobrachium intermedium in southeastern Australia: spatial heterogeneity and the effects of species of seagrass
}

\author{
Charles A. Gray* \\ School of Biological Sciences, University of Sydney, 2006, NSW, Australia
}

\begin{abstract}
The effects of species of seagrass (Zostera capricorni and Posidonia australis) on spatial and temporal heterogeneity in the demography of estuarine populations of the palaemonid prawn Macrobrachium intermedium across $65 \mathrm{~km}$ of the Sydney region, southeastern Australia, were examined. Three estuaries were sampled in 1983 and 1984 to assess the magnitude of intra- and interestuary variability in demographic characteristics among populations. Species of seagrass had no effect on the demographic patterns of populations: differences in the magnitude and directions of change in abundances, recruitment, reproductive characteristics, size structures and growth were as great among populations within each species of seagrass as those between the 2 seagrasses. Abiotic factors, such as the location of a meadow in relation to depth of water and distance offshore, and the interactions of these factors with recruiting larvae are hypothesised to have greater influence than the species of seagrass in determining the distribution and abundance of these prawns. Spatial and temporal heterogeneity in demography was similar across all spatial scales sampled: among meadows (50 $\mathrm{m}$ to $3 \mathrm{~km}$ apart) in an estuary and among meadows in all 3 estuaries (10 to $65 \mathrm{~km}$ apart). Variability in demographic processes among populations in the Sydney region was most likely due to stochastic factors extrinsic to the seagrasses themselves. I conclude that the demography of seagrass-dwelling estuarine populations of $M$. intermedium is basically the same throughout the Sydney region, but differs to that of populations of $M$. intermedium in seagrasses occurring at higher latitudes in southeastern Australia. This study emphasises the need to consider spatial and temporal heterogeneity in the demographic processes of a species over various scales to assess the magnitude of flexibility in its life history throughout its distribution.
\end{abstract}

\section{INTRODUCTION}

Intraspecific variations in the life histories and population dynamics of many marine organisms have been demonstrated over various spatial scales, environmental gradients and throughout time (Strong 1972, Stearns 1976, 1977, 1980, Fletcher 1984, 1987, Etter 1989). Studies on the demography of estuarine and nearshore palaemonid prawns have revealed intraspecific variations among populations occurring in

\footnotetext{
- Present address: Fisheries Research Institute, NSW Agriculture \& Fisheries, PO Box 21, Cronulla, 2230, NSW, Australia
}

different geographic regions and in different habitats and conditions within a geographic region [Beck \& Cowell 1976, Berglund 1980, 1982, 1984, Alon \& Stancyk 1982, Emmerson 1985, 1986, Gray 1991 (companion paper)]. In many of these studies, however, explanations for the differences in demography have been confounded. For example, studies on Palaemonetes pugio (Alon \& Stancyk 1982) and Palaemon pacificus (Emmerson 1986) indicated that certain aspects of their demographies (abundances, reproduction, recruitment, growth and size-structures) differed between populations in different estuaries in the same general geographic region, but also were influenced by different environmental conditions. Both Alon \& Stancyk (1982) 
and Emmerson (1986), however, did not quantitively assess variability within each population or among populations within each estuary. Further, Alon \& Stancyk (1982) did not consider whether differences in demographies between estuaries were consistent in different years. This lack of within-estuary comparisons relies on the assumption that the particular population under study in each estuary is representative of all populations in that estuary, whilst a study which lasts only 1 yr relies on the assumption that patterns are the same in all years.

In the companion paper (Gray 1991), I show that spatial and temporal variability (across $3 \mathrm{yr}$ ) in the demography of 2 populations of the palaemonid prawn Macrobrachium intermedium (hereafter Macrobrachium') in Zostera capricorni and Posidonia australis seagrass meadows in one estuary, Port Hacking, (New South Wales, Australia) was similar to, and of the same magnitude as, the inter-estuary variability in demography described by Alon \& Stancyk (1982) and Emmerson (1986). Further, the magnitude of year-to-year variability in demography of each population in Port Hacking was similar to the variability between populations within each year. I also found that there were no consistent year-to-year differences in the demography of Macrobrachium in these 2 seagrass meadows, hypothesising that species of seagrass had no effect on the demography of Macrobrachium. Further, the general demographic pattern of Macrobrachium in Port Hacking differed to that found previously by Walker (1979), Howard $(1981,1984)$ and Howard \& Lowe (1984) for populations in higher latitudes in southeastern Australia. The consistency of patterns of demography among populations of Macrobrachium in different areas within each of these geographic regions clearly needs to be determined. Further, assessment of variability among populations in similar and different habitats within each geographic region may give some insight into the effects of habitat on the life history characteristics of this species.

In this paper, I investigate the extent of both intraand inter-estuary variability in the demographic characteristics of populations of Macrobrachium in 2 types of seagrass, Zostera capricorni and Posidonia australis, in 3 estuaries across $65 \mathrm{~km}$ of the Sydney region, New South Wales. Firstly, I test the hypothesis that the demography of Macrobrachium does not differ in meadows of different species of seagrass. I compare my findings to those of other studies and discuss factors which may be responsible for determining the distribution and abundance of prawns in seagrasses. Secondly, I report heterogeneity in demography of Macrobrachium over various spatial scales: among meadows (50 $\mathrm{m}$ to $3 \mathrm{~km}$ apart) in an estuary and among meadows in 3 estuaries ( 10 to $65 \mathrm{~km}$ apart). I also provide infor- mation on similarities in the demography of this species in one estuary in studies carried out $7 \mathrm{yr}$ apart. Finally, I compare the magnitude of spatial heterogeneity to temporal heterogeneity and determine seasonal consistencies in spatial heterogeneity for populations of Macrobrachium in these estuaries.

\section{MATERIALS AND METHODS}

Study area. Sampling was done in Zostera capricorni and Posidonia australis seagrass meadows in 3 estuaries (Pittwater, Botany Bay and Port Hacking) across $65 \mathrm{~km}$ of the Sydney region, southeastern Australia (Fig. 1). Zostera and Posidonia meadows in Careel Bay (Pittwater), Quibray Bay (Botany Bay) and at Costens Point (Port Hacking) were sampled seasonally (every $3 \mathrm{mo}$ ) between January 1983 and April 1984. Additional Zostera and Posidonia meadows at Palm Beach (Pittwater) and Towra Point (Botany Bay) were sampled in October 1983, January 1984 and April 1984. Distances between meadows ranged from $50 \mathrm{~m}$ between adjacent Zostera and Posidonia meadows to $3 \mathrm{~km}$ between meadows of the same species of seagrass in different areas in an estuary, and up to $65 \mathrm{~km}$ between meadows in different estuaries. All meadows

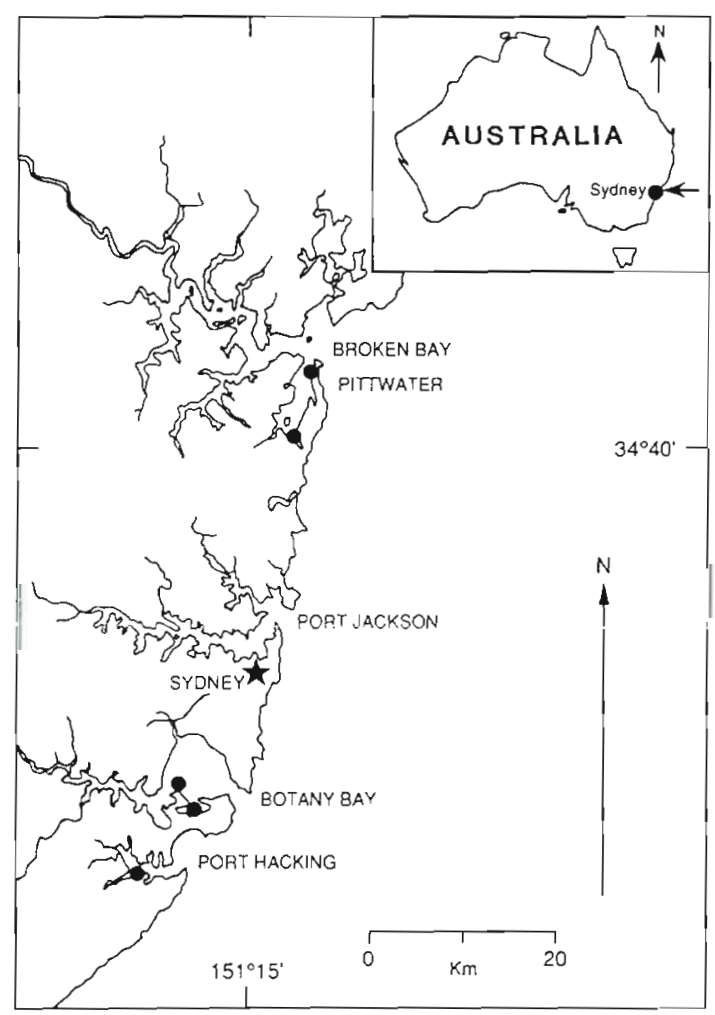

Fig. 1. The Sydney region, showing sampling areas in the 3 estuaries studied: Pittwater, Botany Bay and Port Hacking 
were located in the lower reaches of the estuaries, and influenced predominantly by marine conditions; water salinity ranged between 22 and $35 \mathrm{ppt}$ at the time of sampling in all meadows (Fig. 2). Seasonal changes in water temperature were similar at all meadows, ranging between 14.1 and $22.6^{\circ} \mathrm{C}$ at the time of sampling (Fig. 2). Zostera meadows were generally located in shallower water depths ( 1.2 to $1.5 \mathrm{~m}$ at high tide) than Posidonia meadows (1.3 to $2.4 \mathrm{~m}$ ) (Fig. 2).

Sampling procedure. All meadows were sampled on consecutive days in the middle month of each season, within $3 \mathrm{~d}$ of the full moon and within $2 \mathrm{~h}$ of the morn-
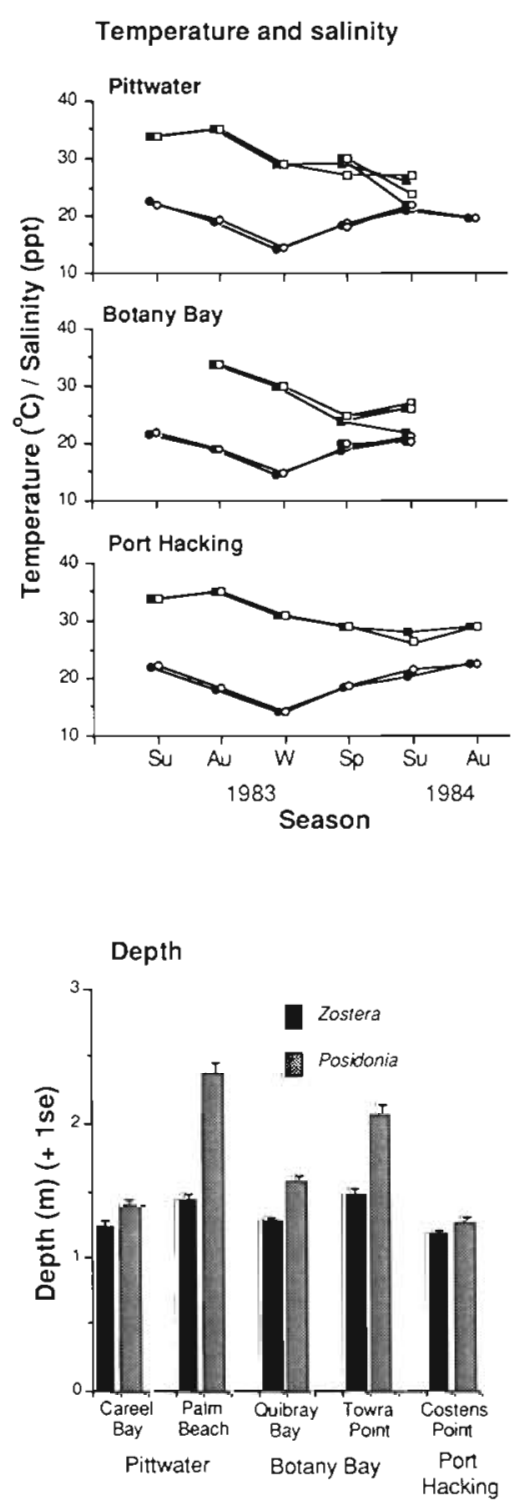

Fig. 2. Changes in temperatures ( $\bullet$ : Zostera capricorni; 0 : Posidonia australis) and salinities (匹: Z. capricorni; $\square: P$. australis) of water at each meadow on each sampling occasion, and mean depth of water at high tide of each seagrass meadow sampled ing high tide. Estuaries, then areas and meadows within each estuary were sampled in a random order. This should have eliminated biases due to differences in the day, time of day and state of the tide. Samples were collected by towing a small beam trawl (Gray \& Bell 1986), $1 \mathrm{~m}$ wide and $0.5 \mathrm{~m}$ high with $2 \mathrm{~mm}$ mesh in the body and $1 \mathrm{~mm}$ mesh in the cod end of the net, at a constant speed behind a small boat over premeasured $20 \mathrm{~m}$ strips of seagrass. Six replicate trawls were done on adjacent but non-overlapping strips of seagrass in each meadow on each sampling occasion. Six trawls were found to minimize variance among replicate trawls with respect to the time taken to collect samples and to the sizes of meadows (Gray 1985). Prior to trawling, the depth, temperature and salinity of water at each meadow were recorded.

All Macrobrachium from each sample were preserved in $10 \%$ formalin, transported to the laboratory, counted, sexed and measured (carapace length; CL) as described in Gray (1991). Juveniles were defined as prawns $<3.1 \mathrm{~mm} \mathrm{CL}$.

\section{RESULTS}

\section{Spatial and seasonal heterogeneity in abundances}

For populations sampled on all 6 censuses, abundances of Macrobrachium varied among meadows and among seasons (significant interaction in ANOVA; Table 1). The numbers of Macrobrachium caught usually differed between the Zostera and Posidonia meadows in each estuary in each season. Abundances were greater in Zostera, except in winter in all estuaries and in autumn 1983 in Port Hacking, when there were no differences in the numbers of Macrobrachium caught in each Zostera and Posidonia meadow, and in spring in Port Hacking, when Macrobrachium were more abundant in Posidonia (SNK tests based on data in Fig. 3). In each season, the numbers of Macrobrachium caught among meadows of the same species of seagrass varied among the 3 estuaries, but no particular meadow or estuary consistently supported the largest populations (Fig. 3).

Seasonal changes in the numbers of Macrobrachium caught were generally similar in all meadows/estuaries (Fig. 3). Abundances of Macrobrachium were usually greatest in summer and least in winter. Two exceptions to this (and cause of the meadow $\times$ season interactions in the ANOVAs of these data; Tables 1 \& 2) were the Posidonia meadow in Careel Bay, which showed no change after winter 1983, and the Posidonia meadow in Port Hacking, where greatest abundances occurred in spring 1983 (SNK tests based on data in Fig. 3). Intraand inter-estuary variability in the magnitude of sea- 
Table 1. Macrobrachium intermedium. Summaries of 2-factor analyses of variance of demographic characteristics in Zostera capricomi and Posidonia australis meadows in Pittwater. Botany Bay and Port Hacking across 6 seasons. Data transformed to $\operatorname{In}(x+1)$ to stabilise variances; Cochran's test after transformations $p>0.05 . \cdots$ Significant $(p<0.001)$

\begin{tabular}{|lrcccc|}
\hline Source of variation & df & $\begin{array}{c}\text { Total no. of } \\
\text { individuals }\end{array}$ & $\begin{array}{c}\text { No. of } \\
\text { juveniles }\end{array}$ & $\begin{array}{c}\text { No. of ovigerous } \\
\text { females }\end{array}$ & $\begin{array}{c}\text { Percentage of } \\
\text { ovigerous females }\end{array}$ \\
\hline $\begin{array}{l}\text { Meadow (M) } \\
\text { Season (Se) }\end{array}$ & 5 & $\ldots$ & $\ldots$ & $\ldots$ & $\ldots$ \\
$\begin{array}{l}\text { M } \times \text { Se } \\
\text { Residual }\end{array}$ & 5 & $\ldots$ & $\ldots$ & $\ldots$ & $\ldots$ \\
Total & 180 & $\ldots$ & $\ldots$ & $\ldots$ \\
\hline
\end{tabular}

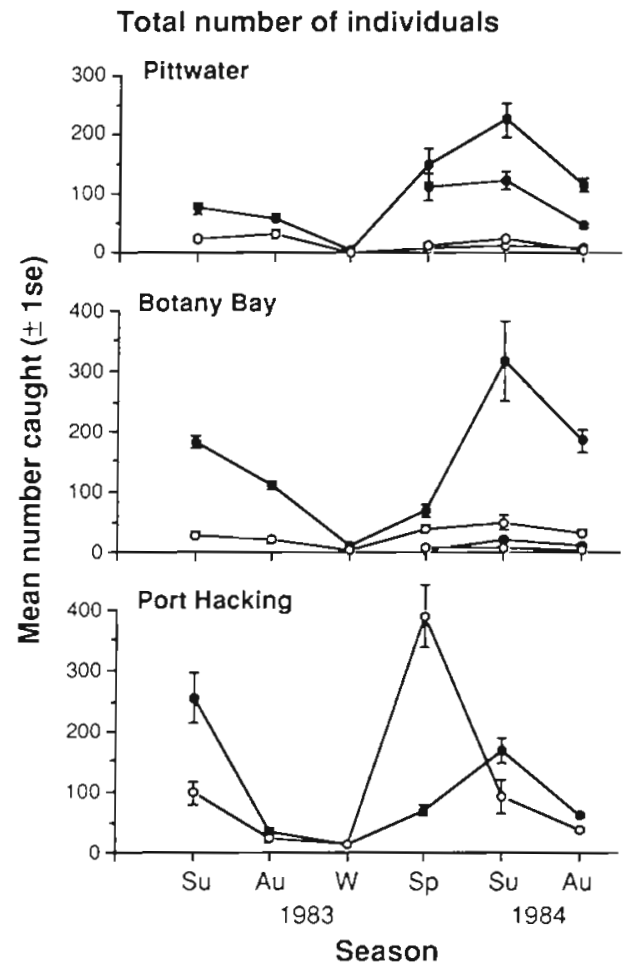

Fig. 3. Macrobrachium intermedium. Seasonal changes in total numbers of individuals caught in $(\bullet)$ Zostera capricorni and (o) Posidonia australis meadows in Pittwater, Botany Bay and Port Hacking

sonal change in the numbers of Macrobrachium caught was similar (Fig. 3).

There was no consistent effect of seagrass species or estuary on the numbers of Macrobrachium caught in Pittwater and Botany Bay over the final 3 sampling periods (significant species of seagrass $x$ estuary interaction in ANOVA; Table 2, Fig. 3). In Botany Bay, abundances of Macrobrachium differed as much between the 2 Zostera meadows as between the Zostera and Posidonia meadows. In Pittwater, however differences in abundances of Macrobrachium were
Table 2. Macrobrachium intermedium. Summary of a 4 -factor analysis of variance of numbers caught in Zostera capricorni and Posidonia australis meadows, each at 2 sites in Pittwater and Botany Bay in spring 1983, summer 1983 and autumn 1984. Data transformed to $\ln (x+1)$ to stabilise variances; Cochran's test after transformation $p>0.05 . \cdot(p<0.05)$ $\cdots(p<0.01), \cdots(p<0.001)$; ns: not significant

\begin{tabular}{|c|c|c|c|c|}
\hline $\begin{array}{l}\text { Source of } \\
\text { variation }\end{array}$ & $\mathrm{df}$ & $\begin{array}{l}\text { Mean } \\
\text { square }\end{array}$ & $F$-ratio & $\mathrm{p}$ \\
\hline Season (Se) & 2 & 7.53 & 66.23 & .. \\
\hline Estuary (E) & 1 & 2.81 & 0.77 & ns \\
\hline Seagrass (Sp) & 1 & 112.65 & 30.95 & $\cdots$ \\
\hline $\mathrm{Se} \times \mathrm{E}$ & 2 & 1.42 & 12.53 & $\cdots$ \\
\hline $\mathrm{Se} \times \mathrm{Sp}$ & 2 & 1.54 & 13.56 & $\cdots$ \\
\hline$E \times S p$ & 1 & 22.14 & 6.08 & $\cdot$ \\
\hline $\mathrm{Se} \times E \times \mathrm{Sp}$ & 2 & 1.93 & 16.97 & $\cdots$ \\
\hline Site (Sp, E) & 28 & 3.64 & 32.03 & $\cdots$ \\
\hline Se $\times$ Site $(S p, E)$ & 56 & 0.11 & 1.68 & . \\
\hline Residual & 480 & 0.07 & & \\
\hline Total & 575 & & & \\
\hline
\end{tabular}

greater between the Zostera and Posidonia meadows than between meadows of the same species of seagrass (SNK tests based on data in Fig. 3).

\section{Abundance of juveniles}

The numbers of juvenile Macrobrachium (defined as $<3.1 \mathrm{~mm} \mathrm{CL}$ ) caught varied among meadows and seasons (ANOVA; Table 1, Fig. 4). Again, there were no consistent trends as to which species of seagrass or in which season the greatest numbers of juveniles were caught (SNK tests based on data in Fig. 4). Juveniles were caught in greater numbers in Zostera in autumn 1983 in all estuaries, whereas in autumn 1984 there were no differences in the numbers of juveniles in Zostera and Posidonia, except at Palm Beach (Pittwater) (Fig. 4). In spring, juveniles were caught in greater numbers in Zostera in Careel Bay (Pittwater), whereas 


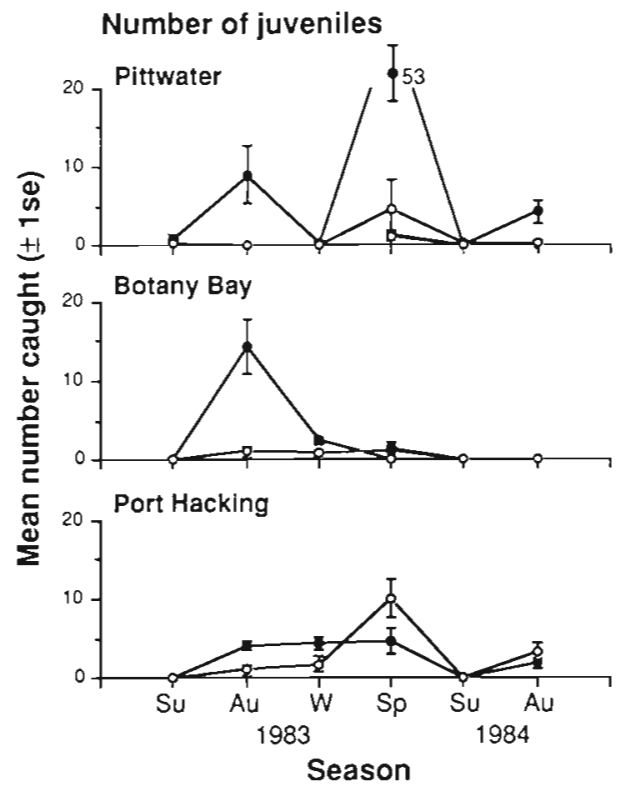

Fig. 4. Macrobrachium intermedium. Seasonal changes in numbers of juveniles caught in ( $\bullet$ Zostera capricorni and (o) Posidonia a ustralis meadows in Pittwater, Botany Bay and Port Hacking

in Port Hacking they occurred in greater abundances in Posidonia, whilst at both localities in Botany Bay and at Palm Beach (Pittwater) their abundances did not differ between Zostera and Posidonia (Fig. 4). At all other times, similar numbers of juveniles were caught in Zostera and Posidonia in each estuary (Fig. 4). Generally, juveniles were usually caught in greater numbers in autumn and spring than in winter and summer (Fig. 4).

\section{Reproductive characteristics of populations}

Ovigerous female Macrobrachium were present in all meadows in all seasons (Fig. 5) and the sizes of the smallest ovigerous females caught were similar in all meadows: between 5.0 and $5.3 \mathrm{~mm}$ CL (Fig. 5). Again, there were no consistent patterns in which species of seagrass or season the greatest numbers and percentages of ovigerous females occurred, both within and among estuaries (significant interaction terms in ANOVAs; Table 1, Fig.5). In some seasons/estuaries the abundances of ovigerous females and the percentages of ovigerous females were greater in Zostera (e.g. Pittwater and Port Hacking in autumn 1983), whereas in other seasons/estuaries the opposite occurred (e.g. Botany Bay in summer 1983; Port Hacking in spring and summer 1984) (Fig. 5). Generally, however, ovigerous females were least abundant in winter, but no general patterns were discernible for the percentage of ovigerous females (Fig. 5).

\section{Size-structures of populations}

There were no striking intra- and inter-species or intra- and inter-estuary differences in the size structures of the populations of Macrobrachium sampled (Fig. 6). Despite the number of cohorts, with their rela-

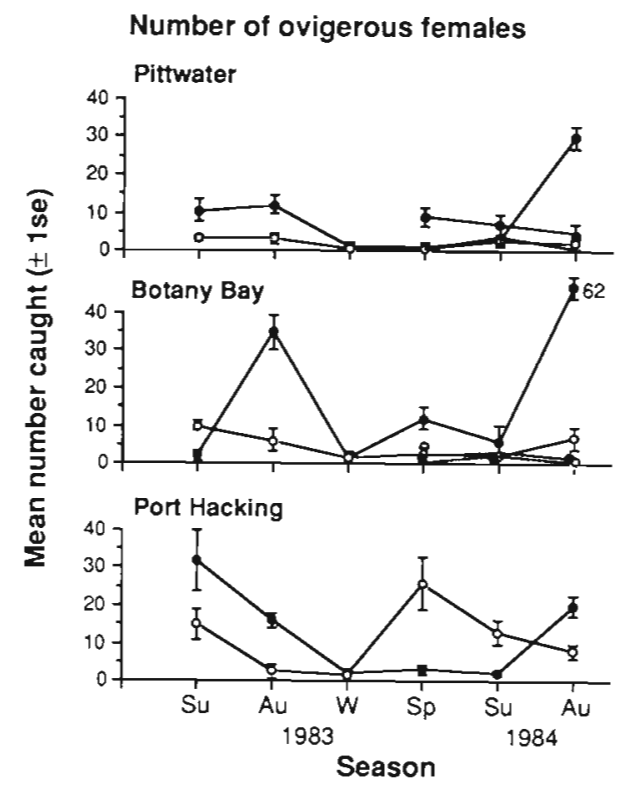

Percentage of ovigerous females

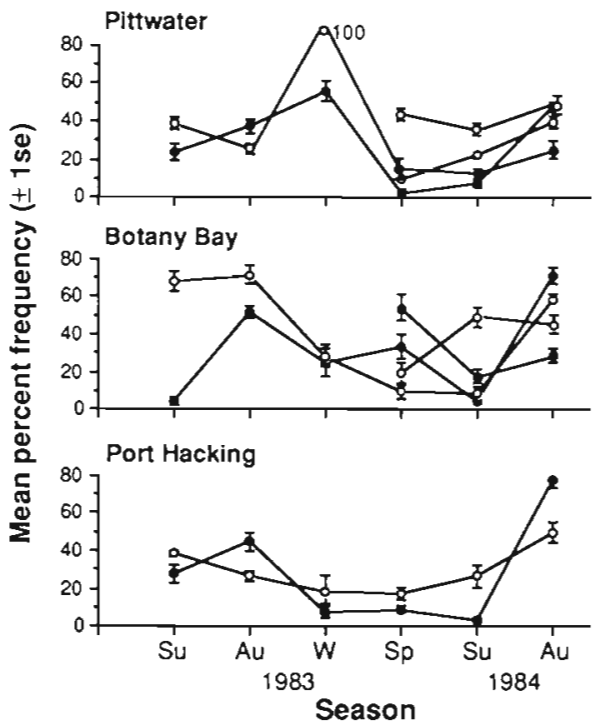

Fig. 5. Macrobrachium intermedium. Seasonal changes in total numbers of ovigerous females and percentages of ovigerous females caught in $(\bullet)$ Zostera capricorni and $(0)$ Posidonia australis meadows in Pittwater, Botany Bay and Port Hacking 


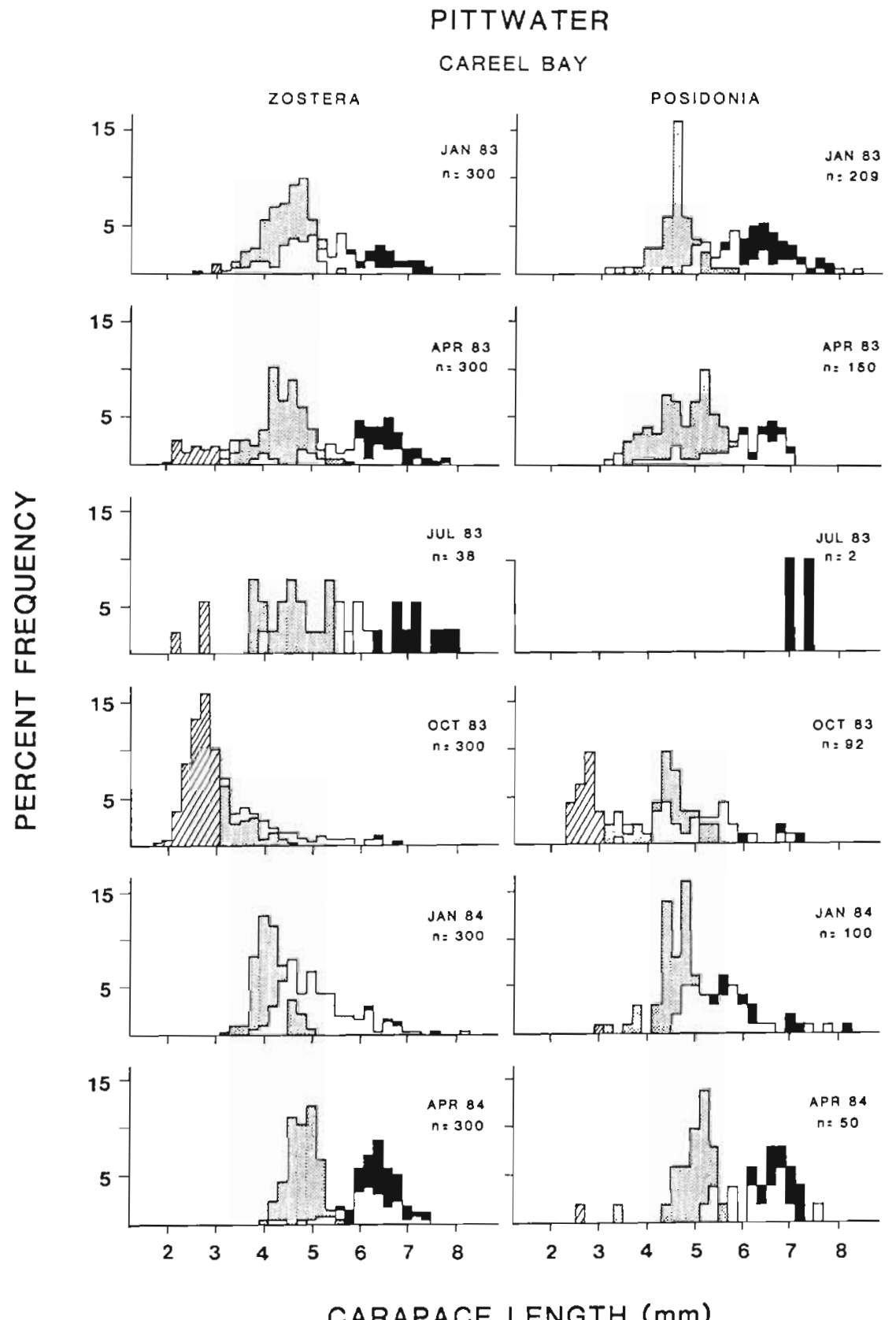

PITTWATER

BOTANY

QUIBRAY
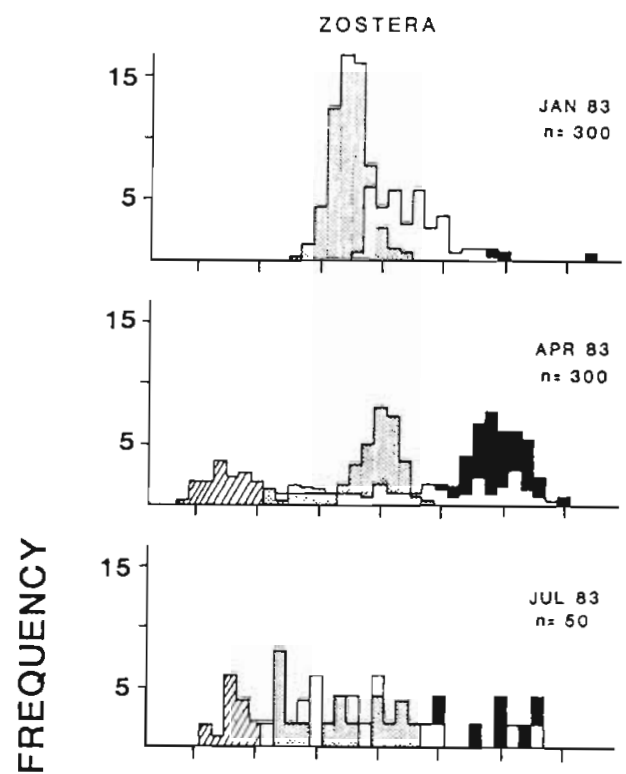

卢
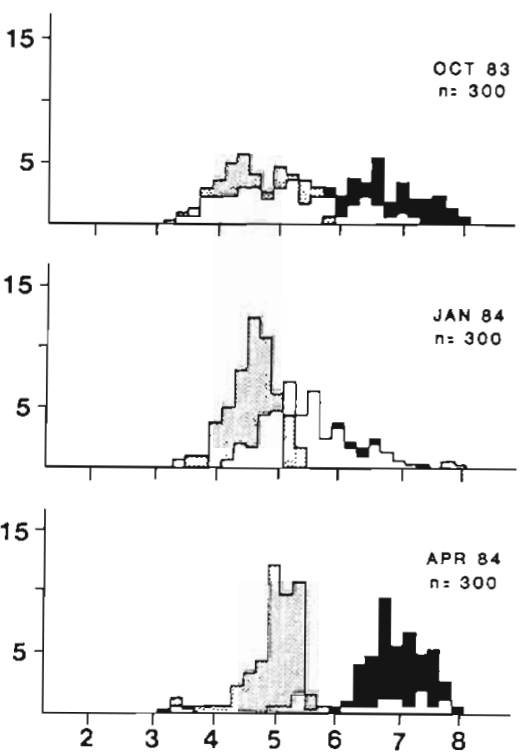

CARAPACE

Fig. 6. Macrobrachium intermedium. Seasonal changes in size frequency distributions of populations in Careel Bay (Pittwater), Quibray Bay (Botany Bay) and Costens Point (Port Hacking). Diagonally shaded bars: juveniles; stippled bars: males; open bars: non-ovigerous females; black bars: ovigerous females

tive predominance and mean size varying among populations, seasonal changes in size-structures of each population were basically the same and equally variable in all meadows (Fig.6). In summer 1983, the size structures of most populations were either bimodal or polymodal. In all meadows, distinct male and female size groups were evident (Fig. 6) and at some sites, for example Zostera in Careel Bay and Posidonia in Port Hacking, a smaller male and female size class was also evident. By autumn 1983 a juvenile size group had appeared in all meadows (except Posidonia in Careel Bay) and all other cohorts had increased in mean size 
present only in the Zostera meadow at Palm Beach (Pittwater) and in both meadows in Port Hacking (Fig.6). The size structures of the additional populations sampled in Pittwater and Botany Bay between spring 1983 and summer 1984 were similar to that described above. Variability in the size structures of populations was equally as great among populations in meadows of the same species as that among meadows of different species and also within each estuary as among estuaries.

\section{Growth}

Growth of Macrobrachium was estimated by changes in the mean sizes (CL) of cohorts between seasons. Individual cohorts of different mean sizes were extracted from the size frequency data for each meadow in each season using probability paper (Cassie 1954) and plotted against time. In each season, cohorts of similar mean sizes were present in most meadows and changes between seasons in the mean sizes of cohorts of similar size were similar in all populations (Fig. 7). In all populations females grew quicker and reached a larger mean maximum CL than males (Fig. 7). The maximum mean CL of cohorts were similar in all meadows: males 5.0 to $5.5 \mathrm{~mm} \mathrm{CL}$; females 7.0 to $8.0 \mathrm{~mm} \mathrm{CL}$.

\section{DISCUSSION}

\section{Effects of seagrass species}

In the companion paper (Gray 1991), I show that differences in abundances, recruitment, reproduction, growth and size-structures of populations of Macrobrachium in adjacent Zostera and Posidonia meadows were not consistent through time, hypothesising that these seagrasses had no effect on these aspects of its life-history. The present study (sampled 7 yr later) shows that this hypothesis holds true for populations of Macrobrachium throughout the Sydney region; there were no consistent differences in any demographic variables of populations of Macrobrachium in Zostera and Posidonia meadows throughout the 3 estuaries sampled. Stoner (1983a) and Lewis (1984) reported that abundances of some species of crustaceans in different seagrasses were not consistently different. In contrast, other studies have found differences in abundances of certain species or groups of organisms between different species of seagrass (Martin \& Cooper 1981, Young 1981, Stoner 1983a, b, Lewis 1984, Middleton et al. 1984, Virnstein \& Howard 1987). Nevertheless, results from most studies suggest that species of seagrass is not the major factor responsible for determining the composition, distribution and abundance of organisms in seagrasses.

Variations in the demographic characteristics of populations of Macrobrachium among meadows (irre-
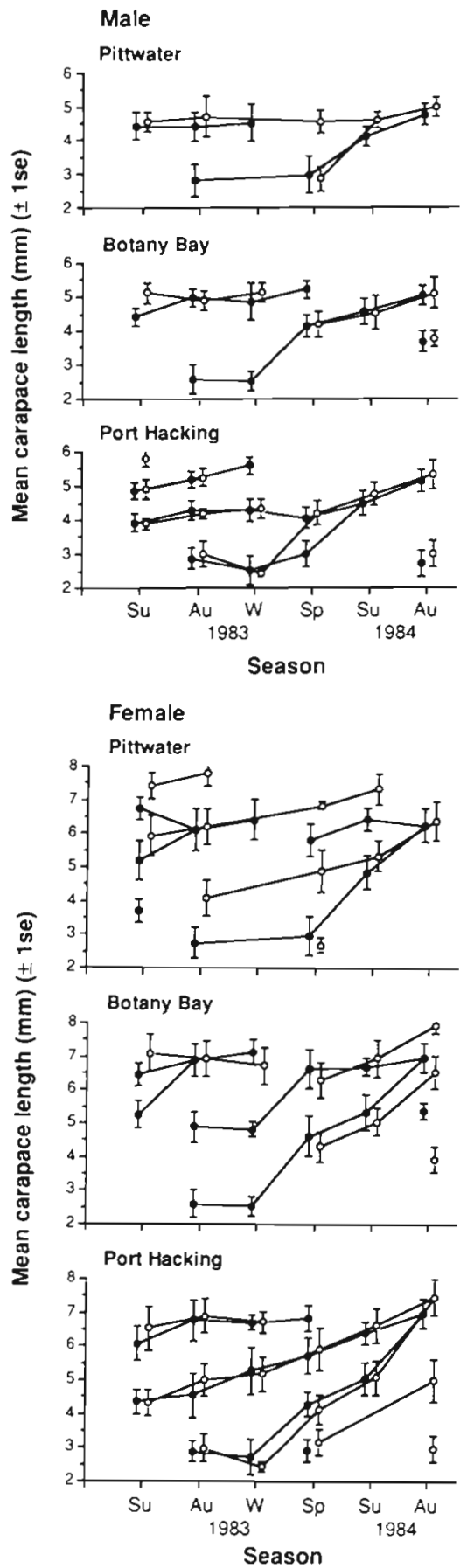

Fig.7. Macrobrachium intermedium. Seasonal changes in mean sizes of male and female cohorts in (•) Zostera capricorni and (0) Posidonia australis meadows in Pittwater, Botany Bay and Port Hacking 
spective of species) were not similar estuary-wide, appeared unique to each meadow/time, and were probably caused by factors extrinsic to the seagrasses themselves. Some variability in abundances of Macrobrachium among the different meadows may have been due to differences in the depth of water and the location of meadows in an estuary. Bell \& Westoby (1986) and Bell et al. (1988) proposed that the distributions and abundances of fish and decapods in seagrasses may be a result of the interactions of the distributions and abundances of larvae and their patterns of settlement (onshore-offshore and upstream-downstream) and the location of meadows in an estuary. Young \& Carpenter (1977) proposed a similar hypothesis to explain the distributions and abundances of postlarval penaeid prawns in estuaries.

Onshore-offshore differences in settlement of larvae have been hypothesised to explain differences in the ichthyofauna between Zostera and Posidonia meadows (Middleton et al. 1984, Bell et al. 1988) and may also explain why I caught most juvenile Macrobrachium in Zostera meadows. Most Zostera meadows I sampled occurred in shallower water, $<0.5$ to $1.0 \mathrm{~m}$, and were located closer to shore than Posidonia meadows. Similarly, Young \& Carpenter (1977) found that postlarval penaeid prawns settled in greater densities in seagrasses in shallow (littoral) than in deeper (infralittoral) depths of water. Further, among the Zostera meadows I sampled, least Macrobrachium were caught at Towra Point in Botany Bay, which lies at a greater depth and further offshore than the other Zostera meadows, and is therefore similar in location to most Posidonia meadows. Wadley (1980) found that abundances of Macrobrachium in Posidonia meadows decreased with increasing depth ( 1 to $4 \mathrm{~m}$ ). In contrast, Baden \& Pihl (1984) reported that 2 other species of palaemonid prawns in western Sweden occurred in greater numbers in seagrasses at depths $>1.5 \mathrm{~m}$ than at depths $<1.5 \mathrm{~m}$. Water depth and distance offshore and upstream are also important in determining the distributions and abundances of postlarval and juvenile penaeid prawns in estuarine seagrasses (Young \& Carpenter 1977, Young 1978). Water depth has also been shown to affect the sizes of prawns and fish in seagrasses (Stoner 1983b, Baden \& Pihl 1984, Middleton et al. 1984, Emmerson 1986). Thus, the location and depth of a meadow may have significant effects on aspects of the demography of prawns in seagrasses, although it appears these factors do not affect all species the same way. Recent research indicates that the location of a meadow in an estuary, rather than the structure of the seagrasses canopy itself, may be more important in structuring communities in seagrasses (Bell \& Westoby 1986, Sogard et al. 1987, Holmquist et al. 1989, Sogard 1989). There have not been enough studies on prawns (carids or penaeids) in seagrasses, however, to ascertain the relative importance of these factors. Different prawns utilise seagrasses in different ways; for example, some species complete their whole life cycle in seagrass areas, whereas in other species only juveniles occur in seagrasses (Young 1977, Howard 1984, Bauer 1985a, b, Emmerson 1986). Similarly, different species also have different habitat requirements; for example, some prawns (carids and penaeids) tend to live on the sediment surface or amongst the seagrass canopy (Bauer 1985a, Howard 1987), whereas others tend to bury into the substratum amongst the roots of seagrasses (Bauer 1985b). Thus different factors may affect different prawns in different ways and generalisations concerning causative factors influencing their distributions and abundances may not be possible. Nevertheless, to fully understand the ways in which different factors influence organisms in seagrasses, it is imperative for future studies to investigate effects on individual species and to assess the consistency of results in space and time.

\section{Spatial and temporal heterogeneity in demography}

There were no consistent differences in the demographic characteristics of populations of Macrobrachium in seagrasses in the Sydney region, and variability in demographic processes was similar over all spatial scales sampled: between populations 0.5 to $3 \mathrm{~km}$ apart in an estuary to populations 10 to $65 \mathrm{~km}$ apart in different estuaries. This spatial heterogeneity in demography was similar to the year-to-year demographic variability in populations of Macrobrachium as described by Gray (1991) for one estuary. Similarly, the seasonal changes in demographic characteristics of populations of Macrobrachium in Port Hacking were the same in this study as those found 5 to $7 \mathrm{yr}$ previously, described by Gray (1991). These studies confirm that the demography of Macrobrachium in seagrasses throughout the Sydney region follows the same general, though variable, pattern, as described in detail by Gray (1991).

Intraspecific variability in the demographies of other palaemonid prawns in similar habitats in different estuaries in the same general geographic region have been shown to occur (Alon \& Stancyk 1982, Baden \& Pihl 1984, Emmerson 1986) and were generally attributed to differing environmental conditions between estuaries. In contrast, I have shown that variability in the demographic pattern of such prawns can differ as much within an estuary as among estuaries and that these variations were probably not solely due to differing environmental conditions between estuaries. It is most likely that these variations in demography of 
Macrobrachium reflect the natural level of stochastic variability in its life history pattern in this region. The previous studies on other palaemonid prawns did not assess within-estuary variability in demographic pattern nor the consistency of differences in demography through time, thus the conclusions reached in those studies differed from that in this study. It needs to be tested whether the demographies of other palaemonid prawns vary as much among different locations within an estuary as between estuaries. This study emphasises the need for adequate replication of treatments throughout appropriate spatial and temporal scales to fully assess variability in life history patterns of a species.

This study confirms that the general demographic pattern of Macrobrachium in seagrasses in the Sydney region differs to that for populations of Macrobrachium in seagrasses in higher latitudes (Victoria and Tasmania) in southeastern Australia (Walker 1979, Howard 1984; see Gray 1991). Briefly, the main differences are that Macrobrachium in the higher latitudes has a reduced period of reproduction (spring to summer), whereas breeding occurs year-round in the Sydney region. Subsequently, recruitment of juveniles is limited to between spring and autumn, peaking in summer, in Tasmania and Victoria, whereas some recruitment occurs all year in Sydney, with peaks in autumn and spring. Thus, there are marked latitudinal differences in some demographic characteristics of seagrass-dwelling populations of Macrobrachium over a distance of $1000 \mathrm{~km}$, but not within the $65 \mathrm{~km}$ area in the Sydney region. Intraspecific variability in life history patterns of various marine organisms occurring in different regions have usually been attributed to differences in environmental conditions between geographic areas (Rothlisberg et al. 1985, Brown-Peterson \& Thomas 1988). Differences in environmental conditions, namely water temperature, may account for differences in the demography of Macrobrachium between these regions in southeastern Australia, but variability in the demography of Macrobrachium populations in the Sydney region was probably due to stochastic pertubations on individual populations. I conclude that variability in demographic characteristics among populations in the Sydney region were stochastic variations on a general underlying pattern which were caused by factors not detected in this study.

Although the demographic pattern of seagrass-dwelling populations of Macrobrachium was similar throughout the Sydney region, this does not say that other populations of Macrobrachium in different habitats (e.g. rock pools or mangrove creeks) in this region do not exhibit different demographic patterns, or that variability in demography among populations in different habitats is not less than that between regions. Populations of other palaemonid prawns occurring in seagrasses and in rock pools in the same geographic region have been shown to portray different demographies (Berglund 1982, 1984, Emmerson 1985, 1986). Similarly, Fletcher $(1984,1987)$ showed that intraspecific variability in the life histories of some species of limpets were greater between intertidal and subtidal populations in the same region than between intertidal populations in different regions. Further research is needed to determine the extent of variability in the demography of Macrobrachium in different habitats throughout its distribution. Such research is essential to determine the plasticity in life history pattern of Macrobrachium and also to assess the effects of environment on the life history characteristics of this species.

Acknowledgements. D. Anderson, S. Kennelly, A. Underwood, D. Ferrell, N. Otway and D. Pollard provided useful discussions and/or criticisms of the draft manuscript. I especially thank my parents for their support throughout this study.

\section{LITERATURE CITED}

Alon, N. C., Stancyk, S. E. (1982). Variation in life-history patterns of the grass shrimp Palaemonetes pugio in two South Carolina estuarine systems. Mar. Biol. 68: 265-276

Baden, S. P., Pihl, L. (1984). Abundance, biomass and production of mobile epibenthic fauna in Zostera marina (L.) meadows, western Sweden. Ophelia 23: 65-90

Bauer, R. T. (1985a). Diel and seasonal variation in species composition and abundance of caridean shrimps (Crustacea, Decapoda) from seagrass meadows on the north coast of Puerto Rico. Bull. mar. Sci. 36: 150-162

Bauer, R. T (1985b). Penaeoid shrimp fauna from tropical seagrass meadows: species composition, diurnal, and seasonal variation in abundance. Proc. Biol. Soc. Wash. 98 . $177-190$

Beck, J. T., Cowell, B. C. (1976). Life history and ecology of the freshwater caridean shrimp, Palaemonetes paludosus (Gibbes). Am. Midl. Nat. 96: 52-65

Bell, J. D., Steffe, A. S., Westoby, M. (1988). Location of seagrass beds in estuaries: effects on associated fish and decapods. J. exp. mar. Biol. Ecol. 122: 127-146

Bell, J. D., Westoby, M. (1986). Variation in seagrass height and density over a wide spatial scale: effects on common fish and decapods. J. exp. mar. Biol. Ecol. 104: 275-295

Berglund. A. (1980). Niche differentiation between two littoral prawns in Gullmar Fjord, Sweden: Palaemon adspersus and $P$ squilla. Holartic Ecol. 3; 111-115

Berglund, A. (1982). Coexistence, size overlap and population regulation in tidal vs non-tidal Palaemon prawns. Oecologia (Berl.) 54:1-7

Berglund. A. (1984). Reproductive adaptions in two Palaemon prawn species with differing habitat requirements. Mar Ecol. Prog. Ser 17:77-83

Brown-Peterson, N., Thomas, P. (1988). Differing reproductive life histories between temperate and subtropical groups of Cynoscion nebulosus. Contr mar. Sci. Suppl. 30: 71-78

Cassie, R. M. (1954). Some uses of probability paper in the analysis of polymodal size distributions. Aust. J. mar Freshwat. Res. 5: 513-522 
Emmerson, W. D. (1985). Seasonal abundance, growth and production of Palaemon pacificus (Stimpson) in eastern Cape tidal pools. S. Afr. J. Zool. 20: 221-231

Emmerson, W. D. (1986). The ecology of Palaemon pacificus (Stimpson) associated with Zostera capensis. Trans. R. Soc. S. Afr 46: 79-97

Etter, R. J. (1989). Life history variation in the intertidal snail Nucella lapillus across a wave-exposure gradient. Ecology 70: $1857-1876$

Fletcher, W. J. (1984). Intraspecific variation in the population dynamics and growth of the limpet, Cellana tramoserica. Oecologia (Berl.) 63: 110-121

Fletscher, W. J. (1987). Life history dynamics of the limpet Patelloida alticostata in intertidal and subtidal environments. Mar. Ecol. Prog. Ser. 39: 115-127

Gray, C. A. (1985). Seasonal dynamics and life history of the palaemonid shrimp Macrobrachium intermedium in seagrass meadows in the Sydney region. M.Sc. thesis, University of Sydney

Gray, C. A. (1991). Temporal variability in the demography of the palaemonid prawn Macrobrachium intermedium in two seagrasses. Mar. Ecol. Prog. Ser. 75: 227-237

Gray, C. A., Bell, J. D. (1986). Consequences of two common techniques for sampling vagile macrofauna associated with the seagrass Zostera capricorni. Mar. Ecol. Prog. Ser. 28: $43-48$

Holmquist, J. G., Powell, G. V. N., Sogard, S. M. (1989). Decapod and stomatopod assemblages on a system of seagrasscovered mud banks in Florida Bay. Mar. Biol. 100: 473-483

Howard, R. K. (1981). The ecology and trophic role of caridean shrimps in the eelgrass community of Western Port, Victoria. Ph.D. thesis, University of Melbourne

Howard, R. K. (1984). The trophic ecology of caridean shrimps in an eelgrass community. Aquat. Bot. 18: 155-174

Howard, R. K. (1987). Diel variation in the abundance of epifauna associated with seagrasses of the Indian River, Florida, USA. Mar. Biol. 96: 137-142

Howard, R. K., Lowe, K. W. (1984). Predation by birds as a factor influencing the demography of an intertidal shrimp. J. exp. mar. Biol. Ecol, 74: 35-52

Lewis III, F. G. (1984). Distribution of macrobenthic crustaceans associated with Thalassia, Halodule and bare sand substrata. Mar. Ecol. Prog. Ser. 19: 101-113

Martin, F. D., Cooper, M. (1981). A comparison of fish faunas found in pure stands of two tropical Atlantic seagrasses, Thalassia testudinum and Syringodium tiliforme. Northeast Gulf Sci. 5: 31-37

Middleton, M. J., Bell, J. D., Burchmore, J. J., Pollard, D. A., Pease, B. C. (1984). Structural differences in the fish com-

This article was presented by A. J. Underwood, Sydney, Australia munities of Zostera capricorni and Posidonia australis seagrass meadows in Botany Bay, New South Wales. Aquat. Bot. 18: 89-109

Rothlisberg, P. C., Staples, D. J., Crocos, P. J. (1985). A review of the life history of the banana prawn Penaeus merguiensis in the Gulf of Carpentaria. In: Rothlisberg, P. C., Hill, B. J., Staples, D. J. (eds.) Second Aust. Nat. Prawn Sem. NPS2, Cleveland, Australia, p. 125-136

Sogard, S. M. (1989). Colonization of artifical seagrass by fishes and decapod crustaceans: importance of proximity to natural eelgrass. J. exp. mar Biol. Ecol. 133: 15-37

Sogard, S. M., Powell, G. V N., Holmquist, J. G. (1987). Epibenthic fish communities on Florida banks: relations with physical parameters and seagrass cover. Mar. Ecol. Prog. Ser. 40: 25-39

Stearns, S. C. (1976). Life history tactics: a review of the ideas. Q. Rev. Biol. 51: 3-47

Stearns, S. C. (1977). The evolution of life history traits: a critique of the theory and a review of the data. Ann. Rev. Ecol. Syst. 8: 145-171

Stearns, S. C. (1980). A new view of life-history evolution. Oikos 35: 266-281

Stoner, A. W. (1983a). Distributional ecology of amphipods and tanaidaceans associated with three seagrass species. J. crust. Biol. 3: 505-518

Stoner, A. W. (1983b). Distribution of fishes in seagrass meadows: role of macrophyte biomass and species composition. Fish. Bull. U.S. 81: 837-846

Strong, D. R. Jr (1972). Life history variation among populations of an amphipod (Hyalella azteca). Ecology 53: $1103-1111$

Virnstein, R. W. Howard, R. K. (1987). Motile epifauna of marine macrophytes in the Indian River lagoon, Florida. 1. Comparisons among three species of seagrasses from adjacent beds. Bull. mar. Sci. 41: 1-12

Wadley, V A. (1980). Spatial and temporal heterogeneity in the epibenthic fauna of estuarine sand and seagrass beds. M.Sc. thesis, University of Sydney

Walker, T. M. (1979). A study of sympatry in two species of Palaemonidae. Ph.D. thesis, University of Tasmania

Young, P. C. (1978). Moreton Bay, Queensland: a nursery area for juvenile penaeid prawns. Aust. J. mar. Freshwat. Res. 29: $55-75$

Young, P. C. (1981). Temporal changes in the vagile epibenthic fauna of two seagrass meadows (Zostera capricorni and Posidonia australia). Mar. Ecol. Prog. Ser. 5: 91-102

Young, P. C., Carpenter, S. M. (1977). Recruitment of postlarval penaeid prawns to nursery areas in Moreton Bay, Queensland. Aust. J. mar. Freshwat. Res. 28: 745-773

Manuscript first received: September 28, 1990

Revised version accepted: June 3, 1991 